\title{
ANALYZING INSTITUTIONAL SUCCESSES AND FAILURES: \\ A MILLENNIUM OF COMMON MOUNTAIN PASTURES IN ICELAND
}

\section{Introduction}

Throughout their history, the island economies of the North Atlantic have relied to a large extent on common property resources both in agriculture and in the fisheries. It is well established that the sharing of resources need not always lead to a full-scale dissipation of wealth, the tragedy of the commons, when certain conditions are met. ${ }^{1}$ However, it is also well known that communities often fail to establish institutions for restricting entry to the commons, and, even when they exist, these institutions are often fragile structures, vulnerable to pressures from population growth, technological change, and shifts in political power and processes. ${ }^{2}$ Therefore, it is of considerable interest to examine the evolution of property rights to natural resources in the North Atlantic communities, such as Iceland, Greenland, and the Faroes, and investigate whether institutions did emerge in these societies that effectively regulated entry and prevented the dissipation of their natural resources. The present study is concerned with the law and economics of Icelandic agriculture, specifically with the institutions that for more than a thousand years have regulated the use of the country's extensive common mountain pastures.

Icelandic agriculture dates back to the rapid settlement of the country in the

1 For instance, see Ostrom (1990).

2 For the problems of contracting for property rights in various environments, see Libecap (1989). 
9th century A.D. ${ }^{3}$ In their ships the settlers brought with them cattle, sheep, horses, goats, pigs, geese, chicken, and dogs and found that the local environment invited the raising of livestock rather than the cultivation of fields. The conditions for grazing were ideal, and, as there were no wild mammals, except the fox, the herds could graze unattended in mountain pastures during the summer months. ${ }^{4}$ In Iceland the farmland and home pastures are primarily in locations all around the coast. Rising above the farmland are the mountain pastures, while a third of the country's 103,000 square kilometers is wilderness with no vegetation. ${ }^{5}$ The mountain pastures are sometimes continuous green areas but often include cliffs, rocks, sands, and wasteland interspersed with vegetation, and, therefore, the grazing animals often must roam far and wide. ${ }^{6}$

The early settlers appear to have claimed land as far as the wilderness of glaciers, sands, and lava in the interior and initially appropriated the mountain pastures that in Icelandic are called afréttir (singular afréttur). In fact, some mountain pastures always have remained exclusive private property, but generally the ownership of the afrettir evolved into communal property. No documentation, however, exists that throws light on how the pastures were divided among the different communities. ${ }^{7}$

In spite of considerable scholarly interest in the question of the commons, the institutional arrangements of the afréttir in Iceland have not been studied by economists, as far as we know. It is now almost a platitude that reliance on common property arrangements may lead to tragedies, and Icelandic society certainly had its share of them. Long-term economic decline, probably beginning in the 13th century, hit bottom in the 18th century-, when the Icelanders came

\footnotetext{
3 Ancient texts say that the settlement of the country was completed in 60 years from about 870 to 930 A.D. See Benediktsson (1974). For an account in English of the early history of Iceland, see Johannesson (1974).
}

4 See p. 214 in Thoroddsen (1919) who still provides the best available history of Icelandic agriculture.

5 See Thoroddsen (1919), pp. 1-30.

6 Thoroddsen (1919), pp. 175-213.

7 Thoroddsen (1919), p. 184 . 
close to extinction. ${ }^{8}$ Furthermore, the country's green areas around the year 1900 are conservatively estimated to be one-half of their size at the time of the settlement in the 9th century and the annual production of vegetation only onethird of the 9th century level. ${ }^{9}$ Historians have blamed centuries of economic decline on foreign rule, adverse external trade relations, volcanic eruptions, pests and plagues, and cooling climate, but the role of the system of property rights in agriculture has received little attention. ${ }^{10}$

In this paper we limit our attention to the structure and consequences of property rights in the communal mountain pastures. We are concerned with the following questions:

a) Why were the afréttir used communally and not divided into exclusive plots for each user?

b) Was the environment of the Icelandic farm districts likely to encourage collective action, and how were the afrettir regulated?

c) Are the rules governing afrettir an example of a tragic solution to the commons problem rather a first best or second best solution?

We proceed in our examination by first briefly introducing certain theoretical concepts before turning to each of the questions above. The theoretical analysis draws on recent work by Ostrom (1990), Field (1986), Russell (1990), and others. The empirical part is based on various published documents, such as the old law codes, records of deeds and judgements, regulations from various periods, a computer search of the Icelandic Sagas, studies by historians and by experts on agriculture, climate and vegetation, and, finally, personal interviews in Iceland

a The economic history of the country is reflected in the average height of the population: "From the age of the settlement down to the 16th century stature remained more or less constant, or about $172 \mathrm{~cm}$. In the 18th century it fell to $167 \mathrm{~cm}$, and about the middle of the 20 th century it rose again to 176.8 . In other words in a period lasting 400 years at the outside, or in the course of 16 generations, the mean stature of the population first falls about $5 \mathrm{~cm}$ and then rises $10 \mathrm{~cm}$ again, a variation of $1 \mathrm{~cm}$ a generation on the average." Steffensen (1958), p.44.

9 Friöriksson (1986), pp.32-33.

20 The drop in temperatures "happened most frequently during the 13th and 14th centuries and during the so-called little ice age in the period between 1600 and $1900 . "$ Fridriksson (1988) p.32. "In these periods the average air temperature may have been 1.5 to $2^{\circ} \mathrm{C}$ lower than it is today in good years, which may have caused a 50\% drop in primary production of the grassland compared with the yield as it had been in good years." Ibid., p.35. 
with agriculturalists, natural scientists, and historians.

\section{A note on theory}

The economics of property rights and, generally, the economics of institutions involve several levels of analysis. A useful initial approach, that I have referred to as the naive model, ignores the supply of institutions and only considers the demand for property rights. ${ }^{11}$ The naive approach suggests that institutions which restrict access to a common property resource emerge when there are net aggregate gains to the community from internalizing the external effects that are associated with open access. ${ }^{12}$ The theory predicts that, given measurement and enforcement costs (transaction costs), an institutional structure will emerge that maximizes the value of the resource. The theory also suggests that overuse and dissipation of a valuable resource will occur when the costs of measurement and enforcement exceed the potential gains from restricting access.

A complete model of institutions requires that we add the supply side to the naive model and, thereby, introduce issues concerning the production of property rights. Property rights are the output of political processes (and also of subtle social processes that are not well understood) and depend not only on the distribution of power and on the institutions for collective action in the community of users but, in many instances, also on the interests, choice set, and institutions of an external authority. For instance, it has been suggested that property rights designed by external authorities, remote from the actual and potential users, are less likely to be efficient in the neoclassical sense than rules set by the users themselves. $^{13}$

In sum, the full model of institutions is based on three constructs:

- the preferences of the relevant individuals,

- their opportunities, and

- the system (and processes) of collective action.

Finally, it should be emphasized that the redistribution of wealth is an important consideration in a full theory of institutional change: new property

11. Eggertsson (1990), pp. 249-277.

12 Demsetz (1967).

13 Ostrom (1990) and Libecap (1990). 
rights always alter the distribution of wealth, and high transaction costs often render it impractical for those who gain from new institutions to compensate the losers. In many groups unanimity (or near unanimity) is required to alter basic property rights, and, when transaction costs are high, only new institutions that make (almost) no one worse off will be considered. ${ }^{14}$

\section{The economic logic of afréttir}

The mountain pastures in Iceland, the afréttir, are a case of joint utilization of a natural resource. Why is it that a natural resource is sometimes divided among individual owners and users and sometimes shared by two or more independent economic units? If we ignore for the moment the question of both political processes and redistribution, the structure of ownership is best explained with three types of production functions: the production function of conventional price theory, the exclusion function, and the internal governance function.

Let us consider cost minimization in terms of the three production functions and briefly illustrate the relevant relationships with reference to a formal model that is due to Field (1986). The cost of exclusion simply refers to the cost of excluding outsiders from the resource (for instance, the cost of fencing and monitoring borders), and the return on exclusion for the insiders takes the form of greater output per unit of input in regular production. Internal governance cost is the cost of preventing free-riding by the insiders who are prone to overuse the resource and dissipate the rent from it. The return on internal governance is the greater net output that results when overexploitation is prevented.

In other words, to minimize the cost of producing any level of output from the natural resource involves a three-fold allocation problem: the allocation of the variable input(s) a) to regular production, b) to exclusion, and c) to internal governance. As always, costs are minimized when the marginal return on the variable input is equal in all uses.

Let us assume that the identical $\mathrm{N}$ members (individuals or firms) of a community of potential users of a natural resource, that measures $\mathrm{R}$ physical units, agree to divide $\mathrm{R}$ into whatever number, $\mathrm{m}$, of equal plots (commons) that

\footnotetext{
14 Russell (1990).
} 
will minimize aggregate costs and maximize the community's net wealth. Then the number of insiders on each plot, $n=N / m$, can be expressed as a function of governance cost, exclusion cost, and a vector representing all other variables, including conventional production costs. In equation (1), a change in $\mathrm{E}$ or $\mathrm{G}$ represents a parametric shift in the exclusion and governance cost curves. ${ }^{15}$

$$
\mathrm{n}=\mathrm{F}(\mathrm{E}, \mathrm{G}, \mathbf{A})
$$

and

\section{$\delta \mathrm{n} / \delta \mathrm{E}>0, \quad \delta \mathrm{n} / \delta \mathrm{G}<0$}

First, note that $\mathrm{n}$, the degree of exclusivity, depends in part on the regular production function of neoclassical economics. In fact, if there are no exclusion and internal governance costs, then $\mathrm{n}$ (the number of firms jointly using each subdivision of $\mathrm{R}$ ) and $\mathrm{m}$ (the number of commons) is determined solely by the economies of scale in production. ${ }^{16}$ Let us assume here that we have constant returns to scale.

If we also assume that the cost of exclusion is a function of the total length of the borders of $\mathrm{R}$, then it is clear that the total exclusion cost reaches the maximum level when $\mathrm{R}$ is divided into $\mathrm{N}$ units with one firm in each, and is at the minimum level when there is only one firm and all $\mathrm{N}$ individuals join together. Let us now consider the implications of shifts in the exclusion function. Other things equal, an upward shift in the cost of exclusion lowers the marginal return on exclusion activities below the marginal returns on the variable input in production and internal governance. In the Field (1986) model, a new equilibrium is established by shortening the borders, which implies that now $\mathrm{R}$ is divided into larger commons and $\mathrm{n}$ is larger than before. Similarly, an innovation that lowers the costs of exclusion (such as low-cost electric fences) moves the solution in the direction of exclusive individual ownership.

Finally, consider the question of internal governance and assume that the cost of preventing any given loss of output from excessive utilization is a direct

\footnotetext{
${ }^{15}$ Note that we present here only a brief and simplified version of the formal model found in Field (1986).

16 Note that it is assumed that $\mathrm{N}$, the total number of firms (or individuals), is a constant.
} 
function of $\mathrm{n}$, the number of insiders. Again, an upward shift in cost of internal governance lowers the marginal return on the variable input allocated to monitoring excessive use by the insiders, and equality of marginal returns is established by reducing $\mathrm{n}$, the number of insiders that use each plot.

We are now ready to consider the logic of ownership in the afrettir in terms of the costs of exclusion, internal governance, and production. The discussion is restricted to the grazing of sheep in the mountain pastures, which has been their most important use. For several reasons exclusion costs for individual plots in the afrettir would be high. First, individual plots would have to be large. The vegetation is often scattered, and the herds of each farmer require a relatively large area to feed on during the summer. Furthermore, as the subarctic vegetation of the highlands is sensitve to climatic changes, grazing conditions vary from one year to another which requires mobile grazing. Second, the cost of monitoring the area would be high. As the flocks did not require protection against wild animals, the monitoring of borders could not be an inexpensive byproduct of shepherding. Third, in historical Iceland, the cost of fencing in the highlands was prohibitive because of the length of the borders, the rugged terrain, and the lack of material for fencing. ${ }^{17}$ However, nature itself often formed natural enclosures with rivers, lakes, wasteland, mountains and glaciers, but in most cases such natural fences enclosed vast areas, sometimes the highland pastures of several farm districts. ${ }^{18}$ Therefore, we conclude that the high exclusion cost in the afrettir indicates that $n$, the number of insiders in each afrettur, should be relatively large, other things equal. However, it should be noted that high exclusion costs in themselves do not rule out that a large afrettur with natural enclosure be privately owned by a rich farmer, the church or even the crown, and the grazing rights sold to a number of

17 For instance, native wood for fencing was not available. In early Iceland some sod and stone fences were erected but mostly to protect home fields. The law code J6nsb6k of 1281 states that farmers who do not fence have no valid claims for compensation when their in-fields are invaded by their neighbors' livestock. It is interesting to note that farmers protested this clause in the Assembly (Althing) when Jonsbok was accepted as law and managed to get the clause abolished in 1294 (except they still had to enclose their storages of fodder). Thoroddsen (1919), p. 99.

18 A dramatic example of a natural enclosure is the mountain range Breidamerkurfjall in southeastern Iceland. To get there the sheep had to be driven over snowcapped mountains as the afréttur is surrounded by glaciers. Thoroddsen (1919), p. 192. 
independent farmers.

The internal governance of an afréttur involves efforts to protect the grazing capacity of the resource by regulating the time of usage and the number of sheep, and by controlling other uses that would reduce the output of vegetation. In the case of joint usage, there is also the internal governance problems of protecting the property right of each farmer in his variable input, the sheep, as the animals mingle in the pastures. In the following section that deals with the regulation of the afrettir we argue that, provided the farm districts were capable of collective action, the technical problem of internal governance in the afrettir was relatively uncomplicated and the corresponding costs low, which also suggests a large $\mathrm{n}$ and a large number of commoners.

Consider now the production costs of using the afrettir. The driving of the sheep into the mountains in summer and back again in the fall, and especially the search for the animals in the vast pastures, are activities that involve positive economies of scale; aggregate costs are lower when the farmers of a district join in these activities rather than when they are performed in isolation. Further, the joint movement of the flocks of a whole district to and from the afrettir would minimize trampling and trespassing on private farmland.

Finally, we note that the relatively low return on fencing in Icelandic agriculture gave rise to various spillover problems that could be handled at a relatively low cost by collective action. For instance, unless some measures were taken, external costs would be imposed on farmers whose unfenced farmland bordered on an afrettur, as the animals could easily stray over onto their land. Costly spillover effects could also be expected if some farmers in a district did not drive their sheep into the afrettir in the summer but let their flocks graze on their unfenced home pastures during the summer, as the sheep might invade the fields of their neighbours.

In sum, the theory suggests that the joint use of the mountain pastures (rather than individual plots) is consistent with the minimization of costs, particularly if the farm communities can overcome the problems of collective action and establish effective institutions for internal governance and the control of spillover effects. We now proceed to examine briefly the basic pattern of utilization of the afrettir and then, in the following section, turn to a more detailed 
examination of the institutions that regulated their use.

The Icelandic Sagas, which deal with events in the 9th to the 11 th centuries but were written one to three hundred years after the events they describe, are the earliest sources of information about the organization of sheep raising in Iceland. Sheep raising is also mentioned in passing in the Sturlunga Sagas, which contain contemporary accounts of the civil war in the 13th century, and in the Bishop Sagas, but the most important source are the extensive law codes of the Icelandic Commonwealth (930-1262 A.D.) preserved in two main manuscripts called Grdgds (which translates "Gray Goose"). ${ }^{19}$

When they lost their independence in the 13th century to Norway (and later to Denmark), the Icelanders received new laws in $1281 .^{20}$ The new law code of 1281 was amended in 1294, 1305, and 1314 and is referred to as Jonsbók. Jónsbók only made modest changes in the laws of Gragas relating to the afrettir and served, with some amendments, as the legal framework in this area into the 20th century. ${ }^{21}$ The laws of Jonsbok regarding the afrettir were finally all preempted with special legislation, No. 42/1969. ${ }^{22}$

Grágás, the ancient law code of the Commonwealth, refers to the afréttir as property jointly owned by two or more individuals and proceeds to enumerate regulations that (in our terminology) relate to exclusion, internal governance, and spillover effects. $^{23}$ In the Icelandic Sagas fleeting references to the organization of sheep farming confirm that already in the first centuries of Icelandic history the alternative use of home pastures in the winter and mountain pastures in the summer and the celebrated search of the mountains for the animals in the fall had

19 The manuscripts of Gragas are called Konungsbok (Codex Regius) and Stadarholsbok. The definitive editions are by Finsen $(1852,1879,1883)$. 1281.

20 We omit to mention the law code Jarnsida that served the Icelanders only from 1271 to

21 The standard edition of Jonsbok is by Olafur Halldorsson (1970) and includes the amendments of 1294, 1305, and 1314. For instance, the laws of the afre'ttir were modified by the new Law of Local Government (Sveitarstjornarlogin) of May 4, 1872.

22 Log um afrffiarmalefni, fjallskil o.fl. Nr. 42/1969. Stjornartidindi A (Offical Gazette A), 1969, pp. 346-57.

23 Gragas (1852) Vol. II, p. 113-22. 
become an essential part of the country's farming practices. ${ }^{24}$ The accounts in the Icelandic Sagas, however, offer little detail of the exact structure of property rights in the afréttir. Sources from the 13th century onward suggest that, over time, many of the afréttir (but not all) had become the communal property of or were managed by one or more local farm communities, called hreppar (singular hreppur), but no documentation exists that describes the transfer of rights from private individuals to the hreppar. ${ }^{25}$

The hreppur is an ancient organization of self-government for the primary rural community. The origins of hreppar are not known, but they already existed in 1096, when the tithe was introduced in Iceland. Gragas requires that all communities have their hreppur, and each hreppur must be a community of at least 20 adjacent farmers in good standing. ${ }^{26}$ In Gragas, and later in Jonsbok of 1281, hreppar are assigned the task of collecting the tithe and maintaining the poor, but the law does not mention that the hreppar oversee the afre'ttir. However, this is probably an omission because the 1294 and 1305 amendments of Jonsbok give the hreppar an active role in regulating the afrettir system, and later court documents confirm that they exercised this authority. ${ }^{27}$

In recent centuries district authorities have published detailed rules governing afre'ttir in their area. For instance, in 1792 a lengthy regulation was

24 The Icelandic Sagas also refer to the practice of driving the flocks from the mountains to a public fold where the sheep were distributed to their owners. For instance, see Svarfdaela saga in Íslendinga sögur (1987), p. 1801.

25 Thoroddsen (1919), pp. 184-5. Historians stress that initially the ownership rights of the hreppar over the afrettir were not clear. Bjornsson (1972), p. 30. Gudmundsson (1981, p. 69) argues that initially the afre'ttir were owned jointly by the farmers of the local community and managed on their behalf by the overseers of the hreppar. In time this distinction became blurred, and eventually it became common for the hreppar to augment the size of the local afre'ttir by purchasing additional pastures, for instance, from the church that was a big landowner.

26 Björnsson (1972), p. 11-32. The legislative body of the Commonwealth could, in exceptional cases, allow fewer than 20 farmers to form a hreppur. Gragas (1852) Vol.2, p. 171. In the Census of 1703, the hreppar numbered about 163, and the country's population was 50,358 . The average population of a hreppur was some 309 persons and about $80 \%$ of the hreppar had a population of 100 to 500 individuals. During the Commonwealth the number if hreppar is estimated at about 150. Björnsson (1972), p. 93, and p. 126.

${ }^{27}$ Bjor̈nsson (1972), p. 66, and various volumes of Diplomatarium Islandicum. 
issued for the afrettir in a county of western Iceland, Borgarfjardarsýsla. ${ }^{28}$. The Local Government Legislation of 1872 required that regulations for afrettir be formally drawn up and published by all districts. These regulations, embodying ancient customs, are found in the Official Gazette of the years following. ${ }^{29}$

The evidence shows clearly that the Icelandic afréttir have been used jointly by independent economic units throughout the country's history, but the evidence also shows that the afrettir are not a case of open access; the use of the resource system has been regulated by small communities of farmers. We now turn to an examination of the nature of these regulations. ${ }^{30}$

\section{The regulation of afrettir}

The provision and enforcement of rules for preserving a jointly used resource, such as the afréttir, have the characteristics of a public good, although the resource itself is not a public good. ${ }^{31}$ Therefore an explanation of the structure of the property rights in common resources that emerges in alternative situations must be based on a comprehensive theory of collective action that so far

28 Lovsamling for Island VI. pp. 16-27.

29 For instance, in the Official Gazette, section, B, there is in 1885 a regulation for the afre'ttir in the hreppar between the rivers Thjdrsá and Hvitá in the county Arnessýsla. The regulation constitutes 96 paragraphs and covers 20 pages in the Gazette (pp. 93-113). These rules are remarkably similar to the laws of Gragas and Jonsbok, except that they are more elaborate and also cover new areas.

30 It should be noted that many afréttir have always been exclusively owned, for instance, by rich farmers or the church, but often rented to the farmers of the district who used the pastures communally. It is not unreasonable to expect that such an exchange between the owner and the users of the afre'ttur is vulnerable to holdups from either side. However, the relationship was apparently governed (at least in some cases) by enforceable long-term (implicit) contracts. For instance, in a legal case from 1584 two farmers in a district in northwestern Iceland sued other farmers of the region for not driving their sheep to the afrettur owned by the two farmers, who thereby lost their revenue from the lamb toll. The former users of the afre'ttur claimed in turn that the output of vegetation on the afre'ttur was unsatisfactory, and they had, therefore, decided to take their sheep elsewhere, to another privately owned mountain pasture where they duly had paid the lamb toll. The justice ruled against the users, as the law requires farmers to continue using their customary afrettur. The judgement also refers to a failure by the dissatisfied farmers to find the proper channel for their complaints and have the quality of the afrettur measured by a third party.

(Althingisbsekur II, pp. 50-52).

31 The afréttir are not a public good because the consumption possibilities by one individual depend on the benefits enjoyed by others. 
is not available. In a major research project, Ostrom (1990) has examined common-pool resource problems in countries throughout the world. ${ }^{32}$ She finds that the users of common-pool resources frequently have been successful in overcoming the temptation to free-ride and act opportunistically and have organized themselves to solve the commons problem, but in other instances cooperation has failed and resources have been wasted on a large scale. Ostrom seeks to account for the factors that contribute to a successful resolution of the common-pool problem, and, at the risk of simplifying her complex theoretical framework, it can be said that she considers factors that affect both the demand for institutions and their supply and associates the emergence of effective institutions with positive net benefits for the individuals involved.

Ostrom's major insights relate to the determinants of the supply side.

Several factors are seen to lower the cost of collective action for small communities that rely on common-pool resources. They include:

1) a clearly defined and stable set of actual and potential users, and a high visibility of users;

2) low discount rates used by potential appropriators (implying continuity, limited alternative opportunities, and a high return on investment in reputation); and

3) comparable interests in the resources by the relevant individuals. $^{33}$

In the case of afrettir most of the factors that contribute to a satisfactory resolution of the commons problem seem to be present. Both the resource and the potential group of users are clearly defined. The afréttir were of critical importance for the farm community which was extremely stable, as was the technology used until the 19th century. Alternative opportunities were few, the farming families had to live with each other for generations, the afrettir had no highly valuable use other than as meadows for grazing, and all the farmers were involved in similar activities. Finally, potential users were compulsory members of a local governance

\footnotetext{
32 In her study of common-pool resources, CPRs, Ostrom (1990) "focused entirely on smallscale CPRs, where the CPR is itself located within one country and the number of individuals affected varies from 50 to 15,000 persons who are heavily dependent on the CPR for economic returns." P.26.

33 The list is not exhaustive. See Ostrom (1990), Chapter 6.
} 
institution, the hreppur, that was fairly autonomous and a flexible instrument for supplying and enforcing rules.

It would be surprising, therefore, to find that the afrettir had been unregulated commons with open access. In fact, we find that they have always been regulated by a detailed body of rules, and cooperation among the users has supplied the collective goods of exclusion, internal governance, and intemalization of spillover effects. Let us consider each of these collective goods in turn.

\section{Exclusion}

The need to restrict entry to the afréttir by outsiders was recognized already in the law codes of the Commonwealth (930-1262), and the laws concerning the afrettir were replicated with relatively minor changes in Jonsbok of 1281 and remained partly in effect into the 19th and 20th centuries. Gragas proclaims the exclusive rights of a group of individuals to an afrettur and states that outsiders require the permission of all the owners of an afrettur before they can use it for grazing. Violations were punishable with a fine. ${ }^{34}$ An individual who wanted to trade his grazing rights in an afrettur to an outsider had to call for an evaluation of aggregate grazing capacity of the pastures and the establishment of individual shares. He was then free to use the share (or the stint) himself or sell it in part or wholly to outsiders.

As both the afrettir and the home pastures generally were not fenced, the exclusive rights of farmers with land bordering on an afrettur had to be protected from intrusions by the unsupervised grazing herds of the mountain pastures. The law books show a great concern for this issue. They require that the flocks be driven into the middle of the afrettur (and not left near the borders). ${ }^{35}$

${ }^{34}$ Gragas (1852), Vol. 2, pp. 113-15. Surviving court documents show that the legal system enforced exclusive rights to the afrettir. For instance, a judgement rendered at Hjardarholt in 1592 concerns the complaint of three hreppar, which shared an afrettur, that farmers from other hreppar had invaded their mountain pastures. The judgement favored the plaintiffs. Althingisbsekur II, p.334.

The rule that an outsider must get permission from all owners of an afre'ttur before he can use it was also enforced. For instance, see a ruling by Thordur Gudmundsson, justice for southern and eastern Iceland, in a case from 1596 where the plaintiff was the church in Reykholt. In his judgement the justice quotes a paragraph from Jonsbok corresponding to the passage from Gragas that we mention above. Althingisbsekur III, pp. 420-421.

35 This requirement is still present in the regulation for Borgarfjardarsysla from 1792. See footnote 28 . Note that the requirement could not be taken literally in the case of vast afrettir that spanned half the way across the country. See Thoroddsen (1919), pp. 198-99. 
Furthermore, the law enumerates various legitimate responses that are open to owners of adjacent land, when flocks of animals from an afrettur invade their property. Also, those who own farmland next to an afrettur have the right to graze their flocks in the afréttur all year long (except for two weeks in the summer), presumably as a form of compensation for trespassing.

Sometimes the afréttir of different communities merge and have no natural boundaries. Various customary rules have evolved to cope with problems that arise in such situations - for instance, the problem of handling wayward animals from neighboring afrettir when the sheep are rounded up in the fall. ${ }^{36}$ Note also that the virtual absence of fencing made it costly for a farmer to protect his fields and home pastures from the wandering sheep of his neighbours, particularly in the summer. The law demanded, therefore, from Gragas onward, that all farmers drive their sheep into the afrettir for the summer or face penalties. Only in exceptional cases, and with the permission of the local authorities, could a farmer be exempted from this rule.

\section{Internal governance}

The internal governance of the afréttir involves two important issues: the preservation of the grazing capacity of the afréttir from overuse by the insiders, and the protection of exclusive individual property rights to the sheep when flocks belonging to a substantial number of different owners mingle unattended in the mountain pastures. We discuss overgrazing in some detail in the last section of the paper, but at this point we note that the law has been conscious of the problem of overgrazing since Gragas. According to Gragas and later Jonsbok, any insider in an afrettur could call for an independent evaluation of the grazing capacity of the pasture. The criterion for optimal usage of an afrettur appears to predate, with modest success, the marginal revolution in economics: the arbitrators were instructed to find the maximum number of sheep that could use the pastures without affecting the average weight of the flock - "let them find that number, which in their judgement does not give fatter sheep if reduced but also fills the

36 For instance, in parts of the district Árnessysla. (Thoroddsen (1919, p.191). A good example of these customs is found in the regulations for the afrettir of hreppar in Árnessýsla from 1895 that reflect ancient customs. Stjdrnarttdindi B (1895), pp. 85-121. 
afre'ttur," says Gragas. ${ }^{31}$ Once the maximum number of animals had been determined, each user of the afréttur was given a quota on the basis of the value of his farm. A farmer who exceeded his quota paid for each additional sheep a penalty to his fellow users that was twice the rent to an outsider for using the pasture, according to Jonsbok.

The basic method for enforcing the property rights of the individual farmers in their sheep, when the flocks were rounded up in the fall, relied on marks on their ears. ${ }^{38}$ Each owner of sheep was required to mark all the members of his flock in the same way before it was sent to the afrettur. Each ear is given a separate mark, which can give rise to a large number of combinations, and the authorities kept careful records of the marks. Some marks were more special than others; the Crown ear-marked its sheep by cutting off both ears, a dangerous mark in the hands of the unscrupulous, as the possessor of such a mark could steal sheep and easily remark the animals without leaving traces of their former marks. ${ }^{39}$

\section{Economies of scale}

The use of vast, unfenced mountain pastures suggests important economies of scale in driving the animals up to the mountains in early summer and in searching the afréttir and driving the flocks down again in the fall, but to realize these gains collective action is required. Furthermore, as the sheep often have to be driven through private farmland on the way to and from the afrettir, trespassing and trampling is minimized if all users of each afretturjoin forces.

Gragas and Jonsbok required the farmers to drive their flocks to the afrettir in a given week in June and round them up and drive them back before a specific

37 Gragas (1852), p. 115. [My translation.]

38 Ear marks are mentioned already in Heidarvïgssaga which many consider the oldest of the Icelandic Sagas, probably written in the early 13th century (dealing with events of the 10th century). In the Saga, Styr, the main character, is enjoying a meal at the home of a neighbor and is served the head of sheep, a traditional Icelandic dish. "And, as they sit at the table, one of Styles men takes the head in his hand and remarks how enormously fat the sheep is. Styr turns and looks at the head and says: "This is an astoundingly great head but do others see what I see, there are no marks on the ears?" [My translation.] Islendinga sogur (1987), p. 1344.

39 Thoroddsen (1919), pp. 330-33. 
week in September. ${ }^{40}$ In 1281, when the law codes of J6nsbok were confirmed by the Assembly (Althing), demands were made that each district be allowed to set its own dates on the basis of local circumstances. These demands were met in the Amendments of 1294 and the right to set the dates given to the overseers of the hreppar. ${ }^{41}$

Rounding up the sheep, often in formidable mountain terrain of a vast scale, and driving them back to the farm district can be major task. In large and rugged afrettir the first search might take a week or ten days, and there were usually at least two sequential search expeditions. ${ }^{42}$ The sheep were driven to a fixed place in each district, a public fold, called rett, and distributed to their owners according to the marks of the ears.

Rounding up the sheep from the afrettir and distributing them to their owners constitute a highly structured activity based on ancient custom, overseen by the management of hreppar and by specially appointed individuals. In the more recent centuries the duties of each sheep-owner were spelled out in a special document, the mountain bill, that was circulated in the district. ${ }^{43}$ Each individual who owned some minimum number of sheep was required to provide one or more persons with supplies, and/or there was a toll to be paid. ${ }^{44}$ The arrangements have been compared with military conscription: each search group was assigned a leader, in the south of the country called fjallkdngur (mountain king), who was given authority comparable to the authority of a military officer. ${ }^{45}$ Early judgements show that some farmers were not satisfied with their share in

40 The law allowed the farmers to leave their animals behind in the afrettir for the winter, but in most cases that was not a practical consideration.

41 Thoroddsen (1919), pp. 205-6.

${ }^{42}$ Descriptions of the customs and adventures of roundups in the afrettir in all districts of the country, in the late 19th and early 20th century, written by the farmers themselves are available in five volumes. Sigurjdnsson, Bragi ed. (1948-52). Gongur og rettir I-V.

43 Björnsson (1972), pp. 184-188; Thoroddsen (1919), pp. 197-207.

44 Some local regulations from the 19th century show that the most difficult areas to search were to be given to those representing rich farmers, except where the search required scaling cliffs, which was assigned to the fittest. (Thoroddsen, 1919, p. 201)

45 Thoroddsen (1919), p. 201. 
the costs of the roundups or even tried to free-ride, but they could be taken to court and fined.

\section{The afrettir:A tragedy?}

In the paper's second part we argued that the joint utilization of the mountain pastures in Iceland, an arrangement operating for more than a thousand years, was rational economically if we allow for transaction costs. In the previous section we first considered the decision environment of the farmers in terms of categories suggested by Ostrom (1990) and concluded that the environment was favorable for collective action to emerge. Furthermore, a search of historical data showed that, already in the Age of the Commonwealth, the farming communities had developed conventions and governance structures that should have prevented large-scale dissipation of wealth in the afrettir. We now turn to actual outcomes and examine whether, indeed, the afrettir are an example of a relatively efficient resource system or a serious case of overcrowding and rent dissipation.

The history of agriculture in Iceland is a sad story of long-term economic decline extending from the 13 th century (or earlier) and into the 19 th century. ${ }^{46}$ The decline is correlated with a drastic reduction in the country's vegetation which, over time, shrank both in terms of area and productivity. A leading botanist of the country maintains "that it is very likely that the primary production of Icelandic vegetation during the 15th century had dropped to half of the amount it was around the time of the settlement." ${ }^{47}$

A drastic reduction in plant production was likely to affect the size of the population, which relied heavily on animal products that in turn were directly related to the output of the natural grassland. Fridriksson (1972) has made a bold attempt to estimate the maximum population that the country's vegetation could support from the time of the settlement until the 19th century, when new technology and new industries rescued the population from the Malthusian bind.

\footnotetext{
46 Thoroddsen $(1919,1922)$.

47 Fridriksson (1986), p. 33. Fridriksson estimates that the annual rate of erosion of fertile land in the last 1000 years has been about 20 square kilometers a year, in total about half of the area of vegetation in the country. In addition, also the average output of the remaining fertile land fell. Fridriksson (1972), pp. 786-7.
} 
Fridriksson concludes that at the time of the settlement the surface area of vegetation was sufficient to support about 70,000-80,000 individuals, but the carrying capacity of the land declined with time, and, at the beginning of the 18th century, the usable crop of the pasture and the hay crop could, in an average year, support only about 55,000 individuals. ${ }^{48}$ These figures are roughly consistent with the estimated actual population.

There does not exist a direct enumeration of the Icelandic population at the time of the Commonwealth, but estimates based on a count of tax-paying farmers in 1095 and other information usually place it around 70,000-80,000. The first census was taken in 1703 , and then the population numbered 50,358, but a smallpox epidemic in 1707-1709 left the country with only some 34,000 inhabitants. ${ }^{49}$ A study by Bishop Hannes Finnsson, published in 1796, that examines the country's annals for evidence of famines reports isolated years of hardship as early as in the middle of the 11th century, famines of rising severity in the 13th and 14 th centuries, and further deterioration in the 17 th century, culminating in the disasters of the 18 th century when the population was nearly erased. ${ }^{50}$

To what extent is this history of decline caused by the practice of the commons, the sharing of the country's mountain pastures? We can only give a tentative answer to this complex question, but consider the simple model in Figure 1. In Figure 1 the line $\mathrm{MB}$ represents the net marginal benefits of adding a sheep to an uncongested mountain pasture. The line is the sum of individual MB lines for the farmers of the district, and it has a negative slope because of diminishing returns for each farmer as he expands his operations. The upward sloping PMC is the private marginal cost of congestion to an individual when he adds more sheep to the pasture; once there is congestion, the weight of the sheep begins to fall as more are added to the pastures. However, when an individual farmer adds a sheep, he imposes cost on the other users of the pasture because their sheep also lose weight, and the aggregate marginal cost of congestion is represented by SMC,

48 Fridriksson (1972) makes clear that the tenuous relationship between fertile land and population "was subject to periodic distortion due to epidemics, affecting sometimes animals and sometimes men, and in both ways contributing to human depopulation." P. 792.

49 Baldursson (1975), p. 23.

60 Finnsson (1970). 


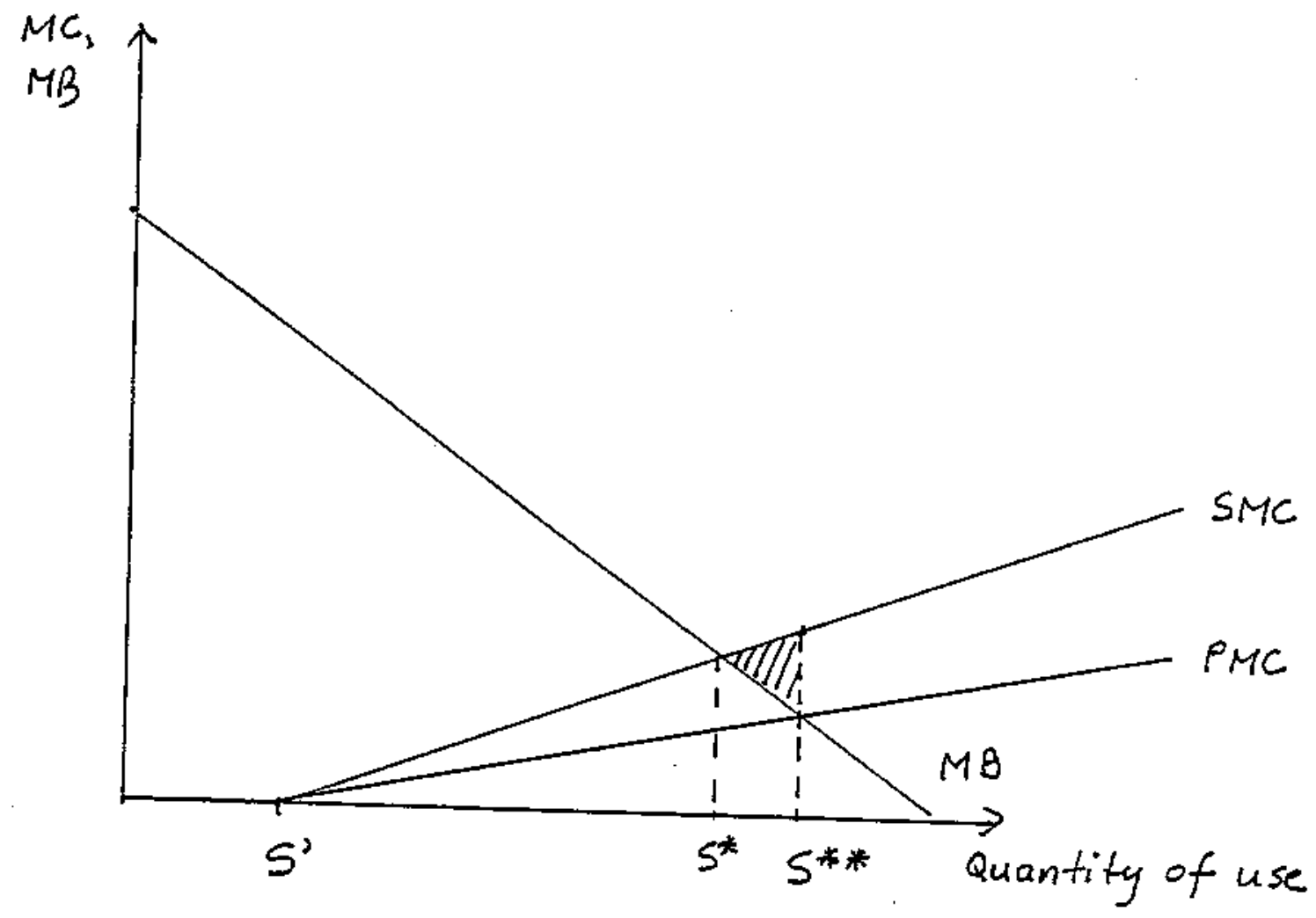

Figure 1

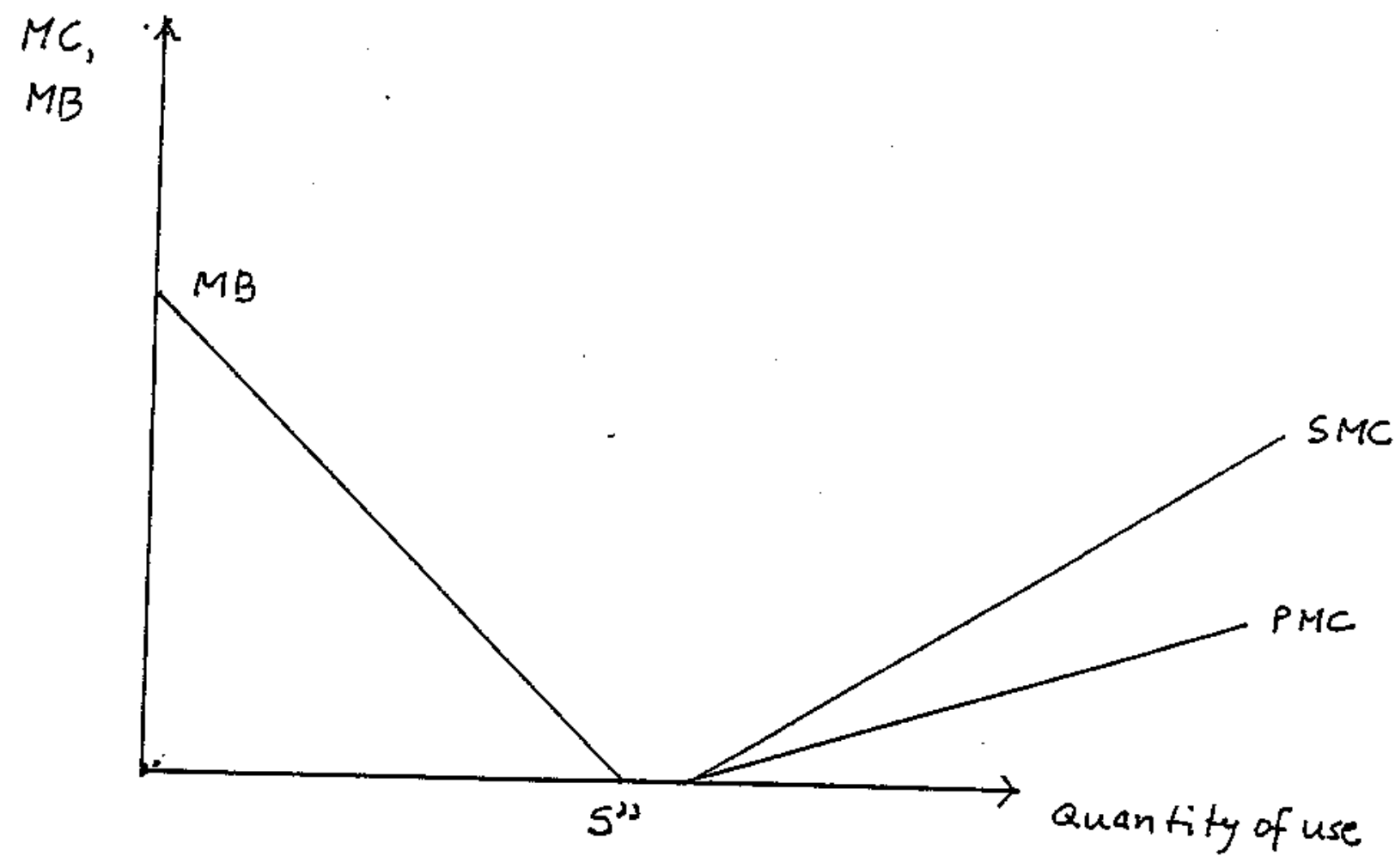

Figure 2 
the social marginal cost. The conventional optimum of price theory is at point $\mathrm{S}^{*}$, where MB and SMC intersect, but in the case of open access the outcome is at $\mathrm{S}^{* *}$ (where MB and PMC intersect), the overuse of the resource is equal to ( $S^{* *}-S^{*}$ ), and the deadweight loss to the community is the shaded area in the diagram.

In the previous section we argued that, already during the Commonwealth, there existed social institutions that should have placed the usage of the afrettir in the neighborhood of S* rather than S'. In fact, Gragas and Jonsbok specify that the appropriate quota for a crowded afirettur is at the point where additional sheep would begin to lower the average weight of the individual sheep in the herd. The aggregate quota of the ancient law codes corresponds to $S^{\prime}$ in Figure 1 and, actually, represents underutilization of the pastures. Also note that the law codes permitted each farmer to either fill his individual quota or sell it (in part or wholly) to another farmer from inside or outside the community, which suggests that the institutions encouraged grazing rights to be allocated to users that valued them most. ${ }^{51}$ As late as the first part of the 20th century, the sheep were not primarily fed on hay in the winter but left to graze on the farmland, and the hay from the relatively small fields was used as a last resort, when winter grazing became impossible. ${ }^{52}$

There is also another consideration. The historical evidence suggests that the capacity of the farmers to feed the sheep in the winter, rather than the carrying capacity of the afréttir during the summer months, was an effective constraint on the size of the livestock. ${ }^{53}$ Only in the 20th century did new technology, that lowered the cost of cultivating the farmland and making hay,

${ }^{51}$ The Icelandic system of afrettir appears to be relatively efficient. For instance, Roberts (1990) makes an interesting theoretical and empirical case for the argument that communities that share a resource usually restrict resale of property rights to members of the community of users or there may be no resale allowed at all. However, it remains to be established whether the quota system was generally used when the afrettir were congested and how prices were determined. In fact, it is doubtful that this information exists.

52 Fridriksson (1972) estimates that in the early 18th century the country's total hay crop was equal to only $10 \%$ of the usable crop from the mountain and home pastures. In the 11th century the proportion was only 5\%, according to Fridriksson (due to a larger output from the pastures and smaller hay fields). P. 792.

63 See Thoroddsen (1919), pp. 278-416, for the history of sheep raising in Iceland. 
begin to relieve the oppressive constraint of winter grazing. ${ }^{54}$

In previous centuries the afréttir in many districts were large relative to the number of sheep that could survive during the winter, and once an area was overgrazed or eroded the sheep could turn or be turned to other sections of the afrettir. If we ignore the costs of rounding up sheep in more distant parts, there was no economic reason for limiting the number of sheep and instituting quotas. This situtation is shown in Figure 2 where the level of utilization is at S", the point where the MB joins the horizontal axis, and there is no congestion. In this context, the afrettir are a free input. The farmers, with their stagnant technology, had no reason to believe that the strict constraint of winter feeding would ever be lifted, and, therefore, it was rational not to be concerned about the gradual erosion of sections of their afrettir.

Why then was there economic decline? We make the case that, once Iceland had been settled in the 10th century, erosion of the vegetation and economic deterioration was the only prospect facing the nation, given the natural environment of the country and the agricultural technology of the times. ${ }^{55}$ Erosion of the sensitive vegetation in Iceland is directly related to deforestation, and deforestation was an unavoidable consequence of the only type of agriculture that was practicable in the country at the time. It is estimated that it took about 200-300 years of clearing, grazing, and charcoal-making to reduce drastically the country's extensive areas of scrub birch and willow and introduce the treeless modern landscape. In this northerly terrain the destruction of the woodlands released a relentless, long-term (and irreversible at the time) process of erosion of the soil that was accelerated by a cooling climate and frequent volcanic eruptions. $^{56}$

Finally, an interesting study yet undone is to examine the response of the Icelandic farmers to their uncertain environment where the size of the livestock,

\footnotetext{
54 Fridriksson (1972), pp. 793-796.

55 McGovern et al. (1988) refer to a transported continental agricultural system at the edge of the climatic tolerance limit. P. 228. Our dire prediction does not allow for the possibility that economic decline could have been averted by a large-scale diversification into fishing (or perhaps other activities) in the Middle Ages.

${ }^{66}$ Fridriksson (1987). "Thrdun Iffrikis Islands og nytjar af Thvi." [The Evolution of the Icelandic Ecosystem and its Utilization.]
} 
and even their own lives, depended on essentially unpredictable but probable events, such as changes in temperatures and volcanic eruptions. ${ }^{57}$ One might expect that communities of rational and risk-averse farmers would evolve institutions for informal insurance that would reduce the risk they faced. In his authoritative study of Icelandic agriculture, Thoroddsen (1919) tells us that typically the farmers did not invest in emergency stocks of hay, that they took the risk of getting through the winter (rather than reducing the stock in the fall), when the number of sheep was unusually large after a good summer, and spurned proposals for cooperative insurance arrangements. ${ }^{58}$ Into the present century it was a part of the Icelandic scene to observe sheep and other livestock starve to death in the late winter and spring. ${ }^{59}$ If Thoroddsen's account is correct, it would be interesting to examine whether the behavior towards risk attributed to the farmers can be explained as economically rational or whether it was a sign of broken spirits in a demoralized community.

57 Bergthorsson (1978) reports that a $1 \mathrm{C}^{\circ}$ reduction in the average annual temperature was in the 19th century associated with almost $30 \%$ reduction in the size of the country's livestock. P. 223.
58 Pp. 354-366.
59 Thoroddsen (1919), p. 357. 


\section{References}

Alpingisbsekur Islands I-X. (1912-1967). [The Books of the Icelandic Althing.] Reykjavik.

Baldursson, Gudni (1975). "Population." in Kristinsson, Valdimar and Nordal, Jóhannes eds. Iceland 874-1974. Reykjavik: Central Bank of Iceland, pp. 22-32.

Benediktsson, Jakob (1974). "Landnám og upphaf allsherjarrikis." [The Settlement and the Origins of the Commonwealth.] In Lindal, Sigurdur, ed. Saga Islands I. Reykjavik: Hid islenska bokmenntafelag, 155-196.

Bjornsson, Lydur (1972, 1979). Saga sveitarstjdrnar a Islandi. Vol. I (1972), Vol. II (1979). [The History of Local Government in Iceland.] Reykjavik: Almenna bokafelagio.

Demsetz, Harold (1967). "Toward a Theory of Property Rights." American Economic Review 57 (May, No. 2): 347-59.

Diplomatarium Islandicum: Islenskt fornbrefasafn, I-XVI. (1857-1952). Sigurdsson, Jon et al., eds. Copenhagen: S. L. Moller. Reykjavik: Felagsprentsmidja:

Eggertsson, Thráinn (1990). Economic Behavior and Institutions. Cambridge: Cambridge University Press.

Field, Barry C. (1986). "Induced Changes in Property Rights Institutions." Research Paper. Amherst: University of Massachusetts, Department of Agriculture and Resource Economics.

Finnsson, Hannes (1970). Mannfsekkun af hallserum. [Fall in Population from Famine.] Reykjavik: Almenna bdkafe"lagi6. Orig. publ. 1796.

Fridriksson, Sturla (1972). "Grass and Grass Utilization in Iceland." Ecology 53 (No. 5): 785-796.

Fridriksson, Sturla (1986). "Factors Affecting Productivity and Stability of Northern Ecosystems." In Gudmundsson, Olafur, ed. Grazing Research at Northern Latitudes. Plenum Publishing, 27-35.

Fridriksson, Sturla (1987). "Throun lifrikis Islands og nytjar af bvi." [The Evolution of the Icelandic Ecosystem and its Utilization.] In Islensk pjodmenning I, Johannesson, Frosti F. ed. Reykjavik: Ijodsaga, pp. 151-194.

Gragas: Konungsbok, Codex Regius (1852) and Stadarholsbok (1879). Finsen, Vilhjálmur ed. Copenhagen: Fornritafélag Nordurlanda.

Gudmundsson, Gunnar F. (1981). Eignarhald a afrettum og almenningum. Sögulegt yfirlit. [The ownership of Mountain Pastures and Commons. An 
Historical Review.] Reykjavik: SagnfraeSistofnun Haskdla Islands.

Jonsbok. Hallddrsson, Olafur ed., (1970). Odense: Odense University Press.

tslendinga sögur (1987). Reykjavik: Svart á hvitu. [The Icelandic Sagas.]

Jóhannesson, J6n (1974). Transl. by Haraldur Bessason. A History of the Icelandic

Commonwealth. Winnipeg: University of Manitoba Press.

Libecap, Gary D. (1989). Contracting for Property Rights. Cambridge: Cambridge University Press.

Lovsamling for Island I-XXI (1853-1889). [Laws for Iceland], Copenhagen.

McGovern, Thomas, et al. (1988). "Northern Islands, Human Error, and

Environmental Degradation: A View of Social and Ecological Change in the Medieval North Atlantic." Human Ecology 16 (No.3): 225-270.

Ostrom, Elinor (1990). Governing the Commons. The Evolution of Institutions for Collective Action. Cambridge: Cambridge University Press.

Roberts, Russell D. (1990). "The Tragicomedy of the Commons: Why Communities Rationally Choose "Inefficient" Allocations of Shared Resources." Political Economy Working Paper No. 140. St. Louis: Washington University, Center in Political Economy.

Sigurjdnsson, Bragi (1948-52). Göngur og réttir I-V. Akureyri: Nordri.

Steffensen, Jon (1958). "Stature as a criterion of the nutritional level of Viking Age Icelanders." In Eldj\&rn, Kristján, ed. Arbók hins islenska fornleifafélags, fylgirit. [Accompanying volume to the Yearbook of the Icelandic Archeological Society], 3951.

Stjornartidindi. [The Official Gazette of Iceland, sections A and B]. Various years.

Thoroddsen, Thorvaldur (1919-1921). Lysing Islands [A Portrait of Iceland], vol. 3, Landbunadur á Iśslandi I [Agriculture in Iceland] (1919), and vol. 4, Landbúnadur á Íslandi II (1921). 